\title{
(5)
}

AL-DZIKRA

Jurnal Studi Ilmu Al-Qur'an Dan Al-Hadits

http://ejournal.radenintan.ac.id/index.php/al-dzikra

Volume 13, No. 1, Juni Tahun 2019, Halaman 27 - 54

DOI://dx.doi.org/10.24042/al-dzikra.v13i1.2970

\section{KISAH QABIL DAN HABIL DALAM AI-QUR'AN: TELAAH HERMENEUTIS}

\author{
Siti Mariatul Kiptiyah \\ STAISPA Yogyakarta \\ sitimariatulkiptiyah1@gmail.com
}

\section{Abstrak}

Tulisan ini membahas tentang bagaimana kisah Qabil dan Habil di dalam al-Qur'an (S. Al-Ma'idah [5]: 27-31) dikaji secara hermeneutis. Dalam kisah ini Qabil diceritakan telah membunuh Habil, adiknya, sebab hanya persembahan Habil yang diterima oleh Tuhan, sementara persembahannya tidak diterima. Kajian ini dilakukan dengan tiga alasan. Pertama, penulis ingin mengangkat kembali kajian kisah dalam al-Qur'an yang dianggap telah 'final', sehingga belakangan sepi peminat bila dibanding dengan kajian ayat-ayat sosial kemasyarakatan dan hukum. Kedua, penulis hendak merekonstruksi pemahaman terhadap kisah tersebut yang selama ini hanya dipahami sebagai kisah orang-orang terdahul__dalam lingkup waktu dan tempat tertentu_dan untuk itulah cukup diyakini kebenarannya saja. Padahal, yang ditonjolkan kisah bukanlah semata-mata unsur benar atau tidaknya, melainkan pesan-pesan terdalamnya. Ketiga, alasan metodologis, di mana kajian tentang kisah terdahulu lebih banyak dilakukan dengan pendekatan historis, sehingga tidak lagi memperhatikan nilai-nilai universalnya, 
bahwa al-Qur'an shalih li kulli zaman wa makan. Untuk itulah, penulis meminjam Hermeneutika Hans-Georg Gadamer sebagai pisau analisis dengan memfokuskan pada teori horizontverschmelzung (penggabungan horizon). Teori tersebut membantu dalam memahami kisah Qabil dan Habil dengan melibatkan horizon pembaca dan horizon teks. Dengan teori tersebut, makna kisah Qabil dan Habil bukan lagi tentang kisah pembunuhan pertama di dunia yang telah berlalu, melainkan dapat ditarik signifikansi maknanya yang universalkontemporer, yaitu tentang konflik antar manusia dan solusinya.

Kata kunci: Hans-Georg Gadamer, horizontverschmelzung, kisah Qabil Habil, konflik.

\section{A. Pendahuluan}

Pembunuhan merupakan tindakan anti kemanusiaan. AlQur'an memotret tindakan tersebut dalam kisah Bani Adam (dalam tafsir disebut bernama Qabil dan Habil). Secara literal, kisah tersebut menceritakan pembunuhan yang dilakukan oleh Qabil terhadap Habil, adiknya. Alasannya adalah ketika keduanya mempersembahkan korban kepada Allah, dan hanya korban Habil yang diterima oleh-Nya. Karena alasan itulah Habil terbunuh. ${ }^{1}$

Kisah ini secara substansi sangatlah menarik. Bahkan Ali Syari'ati dalam On the Sociology of Islam menaruh perhatian tentang kisah Qabil Habil dalam diskursus filsafat sejarah. Menurutnya, sejarah adalah realitas, dan seperti manusia, sejarah berawal dari kontradiksi. Qabil dan Habil adalah manusiamanusia yang manusiawi dan fitri, tetapi keduanya terlibat pertentangan. Satu manusia membunuh manusia lainnya dan dari sanalah sejarah umat manusia berawal, yakni dari pertentangan ekonomi dan dominasi kelas yang direpresentasikan oleh keduanya ketika mempersembahkan korban. ${ }^{2}$

Penafsiran Ali Syari'ati tersebut sangat tepat dan sesuai jika dilihat dari kacamata Sosiologi, mengingat di masyarakat selalu ada pertentangan kelas antara penguasa (Qabil) dan yang dikuasai

${ }^{1}$ Baca: QS. Al-Ma'idah [5]: 27-31.

2 Ali Syari'ati, On the Sociology of Islam, terj. Hamid Algar, (Yogyakarta: Rausyanfikr, 2012), hlm. 143. 
(Habil), yang akan terus berlangsung sepanjang zaman. Akan tetapi, penafsiran yang demikian, terbatas di sudut sosiologi semata dan mengabaikan aspek-aspek yang lain. Dengan kacamata sosiologinya, Ali Syari'ati terhenti pada "motif sosial" apa yang ada di balik terjadinya kisah pembunuhan tersebut. Selain itu, sosiologi tidak mengkaji bagaimana dan dalam rangka apa teks kisah itu muncul yang melibatkan aspek bahasa, konteks, dan sebagainya.

Memang, kisah Qabil dan Habil dapat dilihat dari berbagai sudut pandang. Jika dalam tafsir klasik memandang kisah ini dari sisi historis, ${ }^{3}$ maka pada era-era setelahnya, kisah ini bisa dikaji dari pendekatan naratifnya, ${ }^{4}$ maupun ilmu-ilmu humaniora termasuk sosiologi seperti yang dilakukan Ali Syari'ati. Kendati menggunakan pisau analisis yang berbeda, semua cara baca tersebut ditujukan untuk memahami teks, di mana akan selalu terkait dengan konteks dan kontekstualisasi, ${ }^{5}$ sekaligus selalu melibatkan reader dan authornya. ${ }^{6}$ Maka, untuk mengungkap makna terdalam atas teks tersebut, akan menarik kiranya kita membacanya dengan pendekatan hermeneutika.

Berdasarkan uraian di atas, tulisan singkat ini hendak menelisik kisah pembunuhan Qabil terhadap Habil dengan pendekatan hermeneutika filosofis yang dikembangkan oleh HansGeorg Gadamer. Salah satu teori yang menarik dalam hermeneutika filosofisnya adalah teori horizontverschmelzung (penggabungan horizon). Untuk memahami kisah pembunuhan Habil dan Qabil dalam Al-Qur'an, teori ini mengajak kita tidak hanya melibatkan horizon pembaca melainkan juga horizon teksnya (yang meliputi aspek bahasa, intertekstualitas,

${ }^{3}$ Misalnya; Muhammad bin Ahmad al-Anshari al-Qurthubi, Tafsir alQurthubi, (Beirut: Dar al-Maktabah al-'Alamiyyah, 1971), Ibnu Katsir, Qishshah al-Anbiya', terj. Didi Rosyadi, cet.1 (Jakarta: Al-Kautsar, 2011), dll.

4 Lihat Muhammad Ahmad Khalafullah, Al-Fann al-Qasasi fi alQur'an al-Karim (Kairo: sina li al-nasyr, 1999).

5 Istilah teks, konteks, dan kontekstualisasi dipinjam dari buku; Fakhruddin Faiz, Hermeneutika Qur'ani Antara Teks, Konteks, dan Kontekstualisasi, (Yogyakarta: Qalam, 2003).

${ }^{6}$ Upaya memahami teks dalam segitiga hermeneutika meliputi text, reader, dan author. Lihat: Hans-Georg Gadamer, Truth and Method, pent. Joel Weinsheimer and Donald G. Mar (London: Continuum, 2004). 
intratekstualitas, dan konteks historis teks). Hal ini kiranya cocok untuk menjawab pertanyaan-pertanyaan riset ini, yaitu mengapa al-Qur'an menampilkan kisah pembunuhan dua orang bersaudara, yakni Qabil dan Habil?, dan apa makna terdalam dari kisah itu jika dikaji dalam teori penggabungan horizon (horizontverschmelzung) Hans-Georg Gadamer?.

Setidaknya ada 3 alasan mengapa kisah pembunuhan yang dilakukan Qabil terhadap Habil itu perlu dikaji ulang. Pertama, penulis ingin mengangkat kembali kajian kisah dalam al-Qur'an yang dianggap telah 'final', sehingga belakangan sepi peminat bila dibanding dengan kajian ayat-ayat sosial kemasyarakatan dan hukum. Ayat-ayat kisah yang hanya menceritakan hal-hal di masa lalu, dianggap kurang memberi sumbangsih dalam menjawab persoalan-persoalan sosial. Asumsi tersebut tampaknya perlu di'rebonding'. Kedua, penulis hendak merekonstruksi pemahaman terhadap kisah putra Adam yang selama ini sering dipahami sebagai kisah orang-orang terdahulu _dalam lingkup waktu dan tempat tertentu_dan untuk itulah cukup diyakini kebenarannya saja. Padahal, kisah merupakan bagian dari karya sastra di mana yang ditonjolkan bukanlah unsur benar atau tidaknya. Sepertihalnya karya sastra, ideal moral kisah jarang sekali berupa teks tersurat. ${ }^{7}$

Ketiga adalah alasan metodologis. Fakta bahwa al-Qur'an menempatkan kisah $^{8}$ sebagai tema yang cukup spesial, ${ }^{9}$

7 Dalam karya sastra, pengarang hampir-hampir selalu mengemas makna sesungguhnya secara tersirat. Seperti menjadi kesepakatan umum, bahwa suatu karya sastra lebih tinggi nilainya jika pesan terdalamnya disampaikan secara tersirat. Hal ini mengindikasikan bahwa teks kisah yang lahir di masa lalu, nilai-nilainya masih memungkinkan untuk dikontekstualkan di masa kini. Tidak hanya ibrah-nya melainkan esensi aplikatif atau signifikansinya yang bisa ditarik pada situasi saat ini.

${ }^{8}$ Manna' Khalil Qattan mendefinisikan kisah sebagai pemberitaan alQur'an seputar keadaan umat-umat terdahulu, baik itu tentang kenabian pada masa sebelumnya dan peristiwa-peristiwa yang telah terjadi. Sebab, al-Qur'an banyak memuat kejadian-kejadian masa lampau, dan sejarah umat-umat terdahulu. Lihat Manna' Khalil Qattan, Mabahis fi 'Ulum al-Qur'an, (Riyadh: Mansyurat al-'Asr al-Hadis, 1972), hlm. 306.

${ }^{9}$ Ayat-ayat kisah mendapat porsi hampir seperempat dari jumlah ayat al-Qur'an. Jumlah ini jauh lebih besar dibanding ayat-ayat hukum. Lihat: A. Hanafi, Segi-segi Kesusastraan pada Kisah-kisah Al-Qur'an, (Jakarta: Pustaka 
menjadikannya banyak dikaji. Akan tetapi, sejauh ini, kajian mengenai kisah lebih banyak menggunakan analisis historis ${ }^{10}$ untuk mengungkap secara ontologis kebenaran tentang peristiwaperistiwa yang diredaksikan al-Qur'an. Pertanyaan-pertanyaannya berkisar apakah kisah itu merupakan data sejarah atau bukan, benar-benar terjadi atau tidak. Hal inilah yang kadang-kadang menjadikan penafsiran itu terjebak hanya pada orisinalitas cerita. Yang terjadi kemudian adalah 'mengada-adakan' data historis untuk menguatkan orisinalitas kisah itu. Dalam teori hermeneutika, kelemahan pendekatan historis dikarenakan tidak dapat menjembatani antara makna teks (meaning) dan signifikansinya (significance). Pendekatan historis lebih menampakkan pesan permukaan sebuah teks (surface message) daripada kode-kode yang menggarisbawahi pesan (tersembunyi) dari teks tersebut. ${ }^{11}$

Kaitannya dengan kisah pembunuhan Qabil terhadap Habil dalam al-Qur'an (QS. Al-Ma'idah [5]: 27-31) adalah bagaimana menangkap pesan terdalam dari kisah tersebut. Sebagaimana kita lihat, bahwa kisah tersebut memiliki keunikan yang khas. Narasi kisahnya sangat sederhana, padat, secara langsung fokus pada kejadian tertentu, berada dalam satu rangkaian ayat, tetapi tidak menyebutkan identitas tokoh dengan jelas (hanya sekali menyebut Bani Adam di awal cerita). Sejumlah kitab tafsir menyebutkan bahwa yang dimaksud Bani Adam dalam ayat itu adalah Qabil dan Habil (putra kandung Nabi Adam as). ${ }^{12}$ Sedikit berbeda

Alhusna, 1984), hlm. 22. Pendapat ini juga dikutip oleh Syihabuddin Qalyubi, Stilistika Al-Qur'an, (Yogyakarta: LkiS, 2009), hlm. 1.

10 Muhammad Ahmad Khalafullah pernah mengkritik mufassirmufassir klasik yang mana ketika menafsirkan kisah-kisah al-Qur'an lebih banyak diwarnai dengan pendekatan historis. Sehingga mereka tidak sadar telah melupakan sisi-sisi sosiologis dan keagamaan dari pesan kisah-kisah Al-Qur'an. Lihat Muhammad Ahmad Khalafullah, Al-Fann al-Qasasi fi al-Qur'an alKarim, hlm. 369.

${ }^{11}$ Ini merupakan kritik kaum Strukturalis terhadap Biblical Criticism Biblical Criticism yang lebih terfokus pada kajian historis daripada perkembangan genre teks. Lihat Sahiron Syamsuddin, Hermeneutika dan Pengembangan Ulumul Qur'an, (Yogyakarta: Nawesea Press, 2009), hlm. 67.

12 Lihat: Muhammad bin Ahmad al-Anshari al-Qurthubi, Tafsir alQurthubi, (Beirut: Dar al-Maktabah al-'Alamiyyah, 1971), jilid 5-6, hlm. 88, senada dengan Abu Ja'far Muhammad bin Jarir Ath-Thabari dalam Tafsir Ath- 
dengan Bibel, di mana tokoh kisah tersebut diredaksikan dengan nama Kain dan Habel. ${ }^{13}$

Selain itu, dalam redaksi kisah tersebut terdapat suatu konflik antara dua saudara, yaitu Qabil dan Habil. Kemudian, pada pertengahan kisah, terjadi tindak kriminalitas (pembunuhan), dan di akhir kisah, Qabil sebagai pelaku kejahatan mengalami suatu penyesalan dan kerugian. ${ }^{14}$ Makna kisah tersebut harus direlasikan dengan baik sehingga pesan universal al-Qur'an bisa sampai kepada kita saat ini. Dengan demikian, untuk mendapatkan pemahaman yang objektif-komprehensif, dibutuhkan seperangkat teori penafsiran yang mendalam, yaitu hermeneutika.

Kisah pembunuhan Habil dan Qabil telah banyak dikaji, misalnya oleh Ibnu Katsir, ${ }^{15}$ Bey Arifin, ${ }^{16}$ Shalah al-Khalidy. ${ }^{17}$ Karya ketiganya berupa buku yang memaparkan kisah-kisah AlQur'an secara keseluruhan. Karena memaparkan, maka sifatnya sebatas menyajikan data tentang kisah-kisah tersebut tanpa terkecuali kisah pembunuhan yang dilakukan Qabil terhadap Habil. Karya lain misalnya artikel yang ditulis Achmad, ${ }^{18}$ dalam tulisannya ia menguraikan penafsiran seorang ulama bernama Mutawalli al-Sya'rawi tentang QS. Al-Ma'idah [5]: 27-34 di mana menyangkut kisah Qabil dan Habil. Tetapi, karena metode yang digunakan adalah metode tahlili, maka hasil penafsirannya hampir-hampir serupa dengan Tafsir Ath-Thabari maupun AlQurthubi.

Thabari, jilid 5, terj. Ahmad Affandi, hlm. 863 dan Ibnu Katsir dalam tafsirnya jilid 5 hlm. 163. Begitu juga dengan M. Quraish Shihab, Tafsir Al-Misbah; Pesan, Kesan, dan Keserasian Al-Qur'an (Jakarta: Lentera Hati, 2002), hlm. 92.

${ }^{13}$ Baca: Kitab Kejadian 4: 1-16

${ }_{15}^{14}$ Baca: QS. Al-Ma'idah [5]: 27-31.

${ }^{15}$ Ibnu Katsir, Qishshah al-Anbiya', terj. Didi Rosyadi, cet.1 (Jakarta: Al-Kautsar, 2011).

${ }^{16}$ Bey Arifin, Rangkaian Cerita dalam Al-Qur'an, cet. 15, (Bandung: Alma'arif, 1996).

${ }^{17}$ Shalah Al-Khalidy, Kisah-Kisah Al-Qur'an: Pelajaran dari Orangorang Terdahulu, jilid 3, (Jakarta: Gema Insani Press, 2000).

18 Achmad, "Mutawalli al-Sya'rawi dan Metode Penafsirannya: Studi Atas Surah Al-Ma'idah ayat 27-34" dalam Jurnal Al-Daulah vol 1, no. 2 Juni 2013. 
Dengan demikian, posisi penulis dengan karya ini adalah memberi tawaran berbeda dalam membaca kisah pembunuhan Habil dan Qabil yang terdapat di dalam al-Qur'an. Dengan teori horizonnya Gadamer, penulis tidak hanya menggali satu sisi historis, linguistik, atau kacamata-kacamata sempit, melainkan penulis hendak membuka tabir secara lebih luas atas makna teks kisah tersebut. Penulis berharap penelitian ini memberi kontribusi dalam penafsiran al-Qur'an yang lebih fleksibel sesuai dengan makna al-Qur'an yang shalih li kulli zaman wa makan.

\section{B. Hermeneutika Sebagai Pisau Analisis}

Sebagai sebuah teori interpretasi, ${ }^{19}$ hermeneutika dan tafsir sama-sama berupaya memahami teks untuk menjangkau apa yang dimaksud teks tersebut. Sebab, teks lahir tidak dalam ruang yang hampa budaya. Tetapi, untuk menemukan makna yang relevan, hermeneutika melampaui lebih jauh cara kerja tafsir. Hermeneutika tidak sekedar mengungkap apa yang ada di dalam teks melainkan juga sesuatu yang ada di balik teks, dan yang melingkupi teks tersebut. Karena upayanya menggali makna teks secara mendalam, cara kerja hermeneutika mirip dengan cara kerja filsafat. Hal ini tidak menafikan bahwa hermeneutika secara gen lahir dari rahim filsafat. ${ }^{20}$

Definisi tentang hermeneutika sangatlah beragam. Kata hermeneutika secara etimologis diambil dari bahasa Yunani, yaitu hermeneuein yang berarti menjelaskan atau menafsirkan dan hermeneia (penafsiran/interpretasi). Dari dua kata itu, hermeneutika mencakup tiga hal, yaitu to say (mengatakan), to explain (menjelaskan), dan to translete (menerjemahkan). Untuk itulah, hermeneutika pada dasarnya merupakan salah satu seni menginterpretasi segala sesuatu (dari teks, konteks, perilaku, dan

${ }^{19}$ Secara umum, hermeneutika dapat didefinisikan sebagai teori atau filsafat tentang interpretasi makna. Lihat: Joseph Bleicher, Contemporary Hermenutics, (London: Routledge and Kegan Paul, 1980), hlm. 12.

${ }^{20}$ Secara gen, hermeneutika adalah filsafat. Tetapi kemudian dijadikan sebagai metodologi oleh para pegiatnya di masa-masa awal, seperti Schleirmacher (sebagai peletak dasar hermeneutika), sampai kemudian muncullah Gadamer yang menentang gagasan pendahulunya sekaligus menawarkan hermeneutika filosofis. 
bidang apapun). ${ }^{21}$ Termasuk juga diartikan sebagai seni dan ilmu untuk menafsirkan teks-teks yang punya otoritas, khususnya teks suci. $^{22}$

Karena hermeneutika menawarkan cara memahami teks yang holistik dan mampu memproduksi penafsiran yang lebih progresif, $^{23}$ maka hermeneutika kemudian banyak diminati para intelektual Muslim kontemporer untuk membantu memahami teks al-Qur'an. Misalnya Muhammad Arkoun dengan hermeneutikaantropologi nalar Islam, ${ }^{24}$ Fazlur Rahman dengan hermeneutika double movement, ${ }^{25}$ Nasr Hamid Abu Zayd dengan hermeneutika sastra kritis, ${ }^{26}$ Muhammad Shahrur dengan strukturalisme linguistik, ${ }^{27}$ Hasan Hanafi dengan hermeneutika fenomenologipembebasan, ${ }^{28}$ Amina Wadud dan Fatima Mernissi dengan hermeneutika gender, ${ }^{29}$ Farid Esack dengan hermeneutika pembebasannya, ${ }^{30}$ dan lain sebagainya.

Sedikitnya ada tiga alasan mengapa hermeneutika menarik minat intelektual Muslim. Pertama, stagnasi teks (khususnya al-

21 Richard E. Palmer, Hermeneutika Teori Baru Mengenai Interpretasi,... hlm. 14. lihat juga Sahiron Syamsuddin, Hermeneutika dan Pengembangan Ulumul Qur'an, (Yogyakarta: Pesantren Nawesea Press, 2009), hlm. 5.

22 Kurt F. Leidecker, "Hermeneutics" dalam Dagobert Russel (ed), Dictionary of Philosophy, (New York, Adams \& Co, 1976), hlm. 126.

23 Lihat: Abdul Mustaqim dan Sahiron Syamsuddin (ed.), Studi alQur'an Kontemporer (Yogyakarta: Tiara Wacana, 2002).

${ }^{24}$ Mohammed Arkoun, Tarikhiyyat al-Fikr al-Arabi a-Islami (Beirut: Markaz al-Anma', 1977).

${ }^{25}$ Fazlur Rahman, Islam and Modernity: Transformation of Intellectual Tradition (Chicgo: University of Chicago Press, 1982).

${ }^{26}$ Nasr Hamid Abu Zayd, Mafhum al-Nass: Dirasat fi 'Ulum alQur'an (Kairo: al-Hay'ah al-Misriyah, 1993).

27 Muhammad Syahrur, al-Kitab wa al-Qur'an: Qira'ah Mu'asirah (Damaskus: Dar al-Ahali, 1990).

28 Hassan Hanafi, Muqaddimah fi 'Ilm al-Istighrab (Kairo: Dar alFanniyyah, 1991).

29 Amina Wadud Muhsin, Qur'an and Woman (Kuala Lumpur: Fajar Bakti, 1992) dan Fatima Mernissi, al-Shulthanat al-Munsiyyat: Nisa Raisat Dawlah fi al-Islam, terj. Abd al-Hadi Abbas dan Jamill Mu'alla (Damsyiq: Dar al-Hasad wa al-Tauzi, 1994).

30 Farid Esack, Qur'an, Liberation and Pluralism: An Islamic Perspective of Interreligious Solidarity against Oppression (Oxford: Oneworld, 1997). 
Qur'an) dan dinamika realitas, sehingga untuk tetap "menghidupkan" teks diperlukan dinamika penafsiran demi mengimbangi dinamika realitas tersebut dan hermeneutika dinilai menjanjikan jalan yang prospektif untuk itu. ${ }^{31}$ Kedua, hermeneutika memungkinkan untuk digunakan dalam penafsiran al-Qur'an, sebab, hermeneutika pada hakikatnya adalah penafsiran atas teks juga. Ketiga, hermeneutika menjadikan teks sebagai objek kajian sebagaimana tafsir dan takwil untuk mengungkap makna al-Qur'an, meskipun al-Qur'an adalah teks suci yang berbeda dengan teks lainnya, tapi pada prinsipnya al-Qur'an menggunakan bahasa manusia, yaitu bahasa Arab.

Akan tetapi, tidak semua kelompok Muslim menerima positif dengan kehadiran hermeneutika dalam studi al-Qur'an. Mereka terbagi ke dalam tiga kelompok, yakni liberal, revivalis, dan modernis. Kelompok pertama menerima hermeneutika secara total sebagai bagian dari metodologi penafsiran al-Qur'an. Kelompok kedua menolak hermeneutika secara total dengan alasan teologis. Kelompok ketiga, menerima hermeneutika sebagai salah satu ilmu bantu dalam memahami al-Qur'an namun dengan syarat-syarat tertentu. ${ }^{33}$

Terlepas dari kecenderungan pada salah satu kelompok tersebut, penulis ingin mengatakan bahwa metodologi apapun dapat digunakan untuk membaca al-Qur'an dengan catatan tidak memaksakan, mengedepankan egalitarianisme dalam bahasa Asma Barlas, ${ }^{34}$ serta tidak keluar dari jalur nilai-nilai Qur'ani yang shalih li kulli zaman wa makan. Oleh karenanya, hemat penulis, hermeneutika dapat dijadikan salah satu pendekatan untuk memahami al-Qur'an, dan dalam kajian ini adalah ayat-ayat tentang kisah Qabil dan Habil yang perlu diproduksi ulang progresifitas penafsirannya.

31 M. Amin Abdullah, Islamic Studies di Perguruan Tinggi (Yogyakarta: Pustaka Pelajar, 2006), hlm. 282.

32 Sahiron Syamsuddin, Hermeneutika dan Pengembangan Ulumul Qur'an (Yogyakarta: Nawesea Press, 2009), hlm.72.

33 M. Nurdin Zuhdi, Pasaraya Tafsir Indonesia: Dari Kontestasi Metodologi hingga Kontekstualisasi, (Yogyakarta: Kaukaba Dipantara, 2014), hlm. 28-32.

Asma Barlas, Believing Woman in Islam: Unreading Patriarchal Interpretations of the Qur'an, (Austin, Texas: Texas University Press, 2001). 
Dalam tulisan ini penulis meminjam gagasan Hans-Georg Gadamer. ${ }^{35}$ Gagasan hermeneutika filosofisnya beranjak dari para pendahulunya. ${ }^{36}$ Ia tidak setuju terhadap asumsi kedua pendahulunya yang menyatakan bahwa hermeneutika adalah tugas reproduksi. Sebaliknya, Gadamer menyatakan kemustahilan untuk melakukan reproduksi makna. Sebab, manusia sebagai penafsir tidak berdiri di luar sejarah. Namun, manusia sejatinya bergerak dalam sejarah dengan horizon pemahaman tertentu yang berbeda dari horizon pemahaman di dalam teks atau ungkapan yang hendak dipahami. Maka, prasangka menjadi sebuah kondisi untuk memahami. ${ }^{37}$

Gadamer melihat bahwa hermeneutik dengan interpretasi maknanya tidak hanya reproduktif (menemukan arti yang asli dari suatu teks lalu mencari makna yang oleh si pengarang diletakkan dalam teks itu seperti hermeneutika romantis). Akan tetapi, hermeneutika juga bersifat produktif, ${ }^{38}$ yang berimplikasi terhadap pemaknaan teks. Jadi, makna teks tetap terbuka dan tidak terbatas pada maksud author mengenai teks tersebut. Sebab, ada tiga hal yang saling berkaitan ketika kita dihadapkan pada suatu teks, yaitu understanding (pemahaman), interpretation (penafsiran), dan application (penerapan). Pemahaman merupakan penafsiran, dan penafsiran tidak lain adalah penerapan. ${ }^{39}$

${ }^{35}$ Ia lahir di Marburg pada tanggal 11 Februari 1900 dan meninggal pada 13 Maret 2002 di Heidelberg, Jerman. K. Bertens, Filsafat Barat Abad XX Inggris-Jerman, (Jakarta: Gramedia, 1983), hlm. 233.

36 Misalnya, Schleiemacher dengan hermeneutika romantisnya, ia mengajukan dua hal mendasar yang harus diperhatikan dalam kegiatan menafsirkan teks, yaitu penafsiran gramatikal dan psikologi pengarang. Penafsiran gramatikal (kebahasaan) tidak akan valid tanpa dibarengi dengan penafsiran psikologis. Dengan demikian, pembaca harus merekonstruksi secara imajinatif suasana batin pengarang, memahami pengarang secara lebih baik dari bagaimana pengarang memahami karyanya sendiri. Sedangkan Dilthey dengan gagasan reproduksi makna-nya cenderung kurang memadai. Hal ini karena keduanya mengabaikan gagasan pra-pemahaman.

${ }^{37}$ Hans-Georg Gadamer, Truth and Method, hlm. 278.

${ }^{38}$ That is why understanding is not merely a reproductive but always a productive activity as well. Lihat Hans-Georg Gadamer, Truth and Method, hlm. 296.

39 Gadamer menyinggung hal ini sebagaimana berikut: Hermeneutics was subdivided as follows: there was a distinction between subtilitas intelligendi (understanding) and subtilitas explicandi (interpretation); and 
Pemahaman atau mengerti harus dipandang sebagai sikap yang paling fundamental dalam eksistensi manusia. Sebab, mengerti merupakan cara berada-nya manusia itu sendiri. Eksistensi manusia selalu dibangun oleh kualitas proses pemahamannya, sehingga sangatlah wajar jika Gadamer tidak hanya memusatkan pada tugas filsafat (teori hermeneutis), melainkan juga melewatinya dengan proyek hermeneutisnya. ${ }^{40}$

Apa yang disebut dengan proses pemahaman tidak lain adalah peristiwa sejarah efektif (effective history), yaitu kesadaran tentang situasi hermeneutik. ${ }^{41}$ Efek sejarah atau keterpengaruhan kita pada sejarah senantiasa mempengaruhi pemahaman kita. Menurut teori ini, pemahaman seseorang terhadap suatu teks tidak akan terlepas dari situasi dan kondisi yang melingkupinya. ${ }^{42}$ Termasuk juga epistemologi, ilmu pengetahuan, pengalaman hidup, kepentingan praktis, bahasa, tradisi dan kultur, serta apa saja yang diindra oleh penafsir. Oleh karenanya, suatu penafsiran pasti melibatkan pra-pemahaman, asumsi, prasangka, atau ekspektasi makna dari penafsir. Kesadaran yang dipengaruhi oleh sejarah merupakan kesadaran akan situasi yang menjadi horison pemahaman kita.

Gadamer menegaskan bahwa operasi penafsiran pasti bertolak dari suatu prasangka. Gagasan prasangka memuat sesuatu yang lebih dari tabula rasa (kekosongan), melainkan merupakan tabula plena (kepenuhan). Prasangka memainkan peran awal yang menentukan dalam sebuah penafsiran. ${ }^{43}$ Prasangka berarti sebuah pertimbangan yang diberikan sebelum semua unsur yang menentukan sebuah situasi akhirnya teruji. ${ }^{44}$ Prasangka atau pra-pemahaman adalah asumsi pertama kali yang

pietism added a third element, subtilitas applicandi (application). The process of understanding was regarded as consisting of these three elements. HansGeorg Gadamer, Truth and Method, hlm. 306.

40 K. Bartens, Filsafat Barat Abad XX: Inggris-Jerman (Jakarta: Gramedia, 1990), hlm. 223-224.

${ }^{41}$ Hans-Georg Gadamer, Truth and Method, hlm. 301.

42 Sahiron Syamsuddin, Hermeneutika dan Pengembangan Ulumul Qur'an,... hlm. 37.

${ }^{43}$ Martinho G. da Silva Gusmao, Hans-Georg Gadamer: Penggagas

Filsafat Hermeneutik Modern yang Mengagungkan Tradisi, hlm. 102.

${ }^{44}$ Hans-Georg Gadamer, Truth and Method, hlm. 273. 
ada di dalam otak penafsir ketika membaca suatu teks. Keterpengaruhan seorang penafsir pada konteks di sekitarnya bagaimanapun akan berpengaruh terhadap prapemahamannya terhadap suatu teks. Saat pertama kali membaca teks itu, ia pasti akan memiliki asumsi tertentu terhadap teks yang dibaca.

Tetapi, asumsi ini tidak sekali jadi langsung paten. Asumsi atau prapemahaman harus selalu dipikir-pikir ulang, ditimbang, direhabilitasi, dan dikoreksi oleh penafsir sendiri sampai pada kesempurnaan pemahaman atau minimal ia yakin bahwa asumsinya itu sesuai dengan apa yang dimaksud oleh teks. Hal ini dilakukan agar si penafsir terhindar dari kesalahpahaman terhadap pesan teks tersebut. Terlebih, prasangka sebagai bagian dari ide, mempunyai nilai positif dan negatif. ${ }^{45}$ Dengan demikian, seseorang harus memiliki prapemahaman, tetapi tidak boleh membebaskan prapemahaman itu menghegemoni teks. Prapemahaman hanya sebagai landasan awal bahwa suatu teks itu berbicara sesuatu. Selanjutnya, prapemahaman ini harus disinkronisasikan dengan apa yang ada di dalam teks tersebut. Upaya pensinkronisasian inilah yang disebut dengan fusion of horizon.

Horizon adalah bentangan visi yang meliputi segala sesuatu yang bisa dilihat dari titik tolak khusus. Seseorang yang tidak memiliki horizon, tidak akan bisa melihat sesuatu secara lebih jauh, luas dan dalam, sebaliknya akan menilai sesuatu yang paling dekat secara berlebihan, di mana ini akan terlampaui bagi orang yang mempunyai horizon. Dengan horizon, seseorang juga bisa melihat masa lalu sesuai dengan wujudnya sendiri. ${ }^{46}$

Setiap proses pemahaman, pasti melibatkan dua horizon, yaitu horizon masa lalu dan horizon masa kini. Gadamer menyebutnya horizon of the past and horizon of the present. Hubungan keduanya adalah bahwa horizon masa lalu selalu membentuk horizon historis, dan horizon masa kini tidak dapat dibentuk tanpa horizon masa lalu. Jadi, pemahaman selalu merupakan gabungan dari horizon-horizon yang kita bayangkan ada dengan sendirinya ${ }^{47}$

\footnotetext{
${ }^{45}$ Hans-Georg Gadamer, Truth and Method, hlm. 273.

${ }^{46}$ Hans-Georg Gadamer, Truth and Method, hlm. 301.

${ }^{47}$ Hans-Georg Gadamer, Truth and Method, hlm. 305.
} 
Dalam proses penafsiran, istilah lain untuk horizon masa lalu adalah horizon teks, sedangkan horizon masa kini adalah horizon pembaca. Untuk memperoleh pemahaman yang objektifkomprehensif, maka keduanya harus disatukan yang disebut dengan fusion of horizon. Oleh karena itulah mengapa prapemahaman terhadap suatu teks harus selalu dipikir-pikir ulang, ditimbang, dan dikoreksi oleh penafsir sendiri sampai pada kesempurnaan pemahaman, sebagaimana dibahas sebelumnya. Prapemahaman seorang penafsir yang telah dipengaruhi oleh konteks tertentu merupakan bagian dari horizon pembaca. Sedangkan horizon teks adalah suatu pengetahuan yang ada di dalam teks dan berkaitan dengan situasi atau konteks teks tersebut.

Jika teks yang dimaksud adalah ayat al-Qur'an, maka horizon teks ini adalah aspek kebahasaan, intertekstualitas, intratekstualitas, dan konteks historis suatu ayat. Ini sangat membantu untuk menemukan mengapa teks itu muncul dan berbunyi demikian, sehingga penafsir dapat mengerti maksud teks tersebut. Jadi, pada teori asimilasi horizon ini menganjurkan penafsir melakukan dua studi sekaligus yaitu_meminjam bahasanya Amin Al-Khulli_dirasat ma fi al-nashsh dan dirasat ma hawla al-nashsh (apa yang ada di dalam teks dan yang melingkupi teks). ${ }^{48}$

Interaksi antara horizon pembaca dan teks inilah yang disebut lingkaran hermeneutik. Gadamer mengatakan bahwa horizon pembaca hanyalah sebagai titik berpijak seseorang dalam memahami teks. Titik berpijak ini tidak lain hanyalah pendapat atau kemungkinan bahwa teks berbicara sesuatu. Maka titik pijak ini tidak boleh dibiarkan memaksa pembaca agar teks harus berbicara sesuai dengan titik pijaknya. Sebaliknya, titik pijak ini justru harus bisa membantu memahami apa yang sebenarnya dimaksud oleh teks. Di sinilah terjadi pertemuan antara subyektivitas pembaca dan obyektivitas teks, di mana makna obyektif teks lebih diutamakan. ${ }^{49}$

48 Sahiron Syamsuddin, Hermeneutika dan Pengembangan Ulumul Qur'an,... hlm. 84-85.

49 Sahiron Syamsuddin, Hermeneutika dan Pengembangan Ulumul Qur'an,... hlm. 40. 
Sebagaimana dikatakan Gadamer, gagasan hermeneutika filosofisnya bukanlah sebuah metodologi, namun, sejumlah teorinya dapat digunakan untuk membantu penafsiran. Karena penafsiran juga merupakan pemahaman, upaya maka penafsiran terhadap kisah putra Adam dalam al-Qur'an adalah upaya memahami kisah tersebut. Digunakannya hermeneutika Gadamer sebagai pisau analisis adalah karena dalam upaya memahami teks, Gadamer melibatkan horizon teks dan horizon pembaca sekaligus. ${ }^{50}$ Hal ini akan menjadikan suatu teks selalu relevan di manapun dan kapanpun, serta tidak terkesan spasio temporal. Ini senada dengan universalitas nilai-nilai al-Qur'an, bahwa al-Qur'an adalah shalih li kulli zama wa makan. Dengan begitu, nilai-nilai kisah putra Adam dalam al-Qur'an menjadi 'kontemporer' sepanjang masa.

\section{Analisis Kisah Qabil dan Habil Telaah Teori Horizont verschmelzung}

Kisah tentang pembunuhan yang dilakukan oleh Qabil terhadap Habil dalam al-Qur'an diredaksikan dalam lima ayat. Rangkaian kisah tersebut seluruhnya tercantum dalam QS. AlMa'idah [5] : 27-31. Sebagaimana kita ketahui bahwa surat AlMa'idah termasuk surat Madaniyah. Karakteristik surat Madaniyah selain turun di Madinah, inti dari ayat-ayatnya berbicara tentang syariat Islam yang lebih luas. Di dalam alQur'an hanya ada lima ayat yang menyebutkan istilah bani Adam, salah satunya adalah kisah Qabil dan Habil. Selain digunakan untuk membahas kisah yang tercantum dalam surah Al-Ma'idah ini, semuanya terdapat dalam satu surah yaitu surah Al-A'raf. ${ }^{51}$

${ }^{50}$ Konsep ini hampir sama dengan gagasan Abid Al-Jabiri dengan teori Al-Fashl dan Al-Washl. Lihat Abid Al-Jabiri, Nahnu wa al-Turats: Qira'ah Mu'ashirah fi Turatsina al-Falsafi, (Beirut: Al-Markaz al-Tsaqafi al-Arabi, 1993), hlm. 12. Penulis tidak memilih konsep Al-Jabiri untuk membaca teks kisah putra Adam karena penulis masih meragukan adakah keterpengaruhan pemikiran Al-Jabiri dengan Gadamer, mengingat meskipun keduanya hidup berjauhan (Jerman dan Maroko) tetapi Gadamer lahir 35 tahun lebih awal dari Al-Jabiri. Selengkapnya lihat Wahid Harmeneh, "Pengantar" dalam Al-Jabiri, Kritik Kontemporer atas Filsafat Arab Islam, terj. M. Nur Ichwan (Yogyakarta: Islamica, 2003), hlm. xvii-xviii.

${ }^{51}$ QS. Al-A'raf [7]: 26 berbicara tentang macam-macam pakaian yang dianugerahkan oleh Allah. QS. Al-A'raf [7]: 27 membicarakan larangan 
Menarik untuk dicermati, bahwa penyebutan bani Adam dalam alQur'an semuanya tergolong surat Madaniyyah. Dengan demikian, pesan ayat yang menggunakan istilah bani Adam, tentu tidak untuk tujuan khusus, melainkan diperuntukkan kepada masyarakat secara luas.

Dalam teori horizontverschmelzung sebagaimana telah dibahas di awal, maka dalam menghadapi teks kisah pembunuhan Qabil terhadap Habil dalam al-Qur'an harus menyelaraskan antara horizon pembaca dengan horizon teks. Yang termasuk horizon teksnya adalah aspek kebahasaan ayat, intratekstualitas (hubungan ayat dengan ayat lain di dalam al-Qur'an yang setema), intertekstualitas (hubungan ayat dengan teks-teks lain di luar al-Qur'an; hadis, riwayat-riwayat terdahulu, Bibel, dan sebagainya), dan historical context (konteks historis yakni asbabun nuzul ayat baik mikro ataupun makro).

Secara ringkas, QS. Al-Ma'idah [5]: 27-31 membicarakan tentang konflik antara dua putera Adam (Qabil dan Habil) yang mana Nabi Muhammad saw diperintah oleh Allah untuk membacakan kisah tersebut kepada orang-orang Yahudi. Kisah tersebut berawal dari Qabil dan Habil mempersembahkan korban, tetapi hanya korban Habil yang diterima. Qabil kemudian mengancam akan membunuh Habil. Jawaban Habil adalah sesungguhnya Allah hanya menerima korban dari orang yang bertaqwa.

Penyebutan 'Bani Adam' dalam ayat tersebut bisa jadi maksudnya adalah Qabil dan Habil, tetapi tidak menutup kemungkinan adalah tokoh fiktif yang merepresentasikan manusia (karena hanya manusia yang mempersembahkan korban dan cerita selanjutnya lebih banyak mengungkap karakter manusia). Dalam suatu kisah atau karya sastra, tokoh menjadi unsur sentral dalam penyampaian suatu cerita. Menurut penulis, tidak terlalu penting mengungkap fiktif atau tidaknya tokoh dalam kisah tersebut. Tetapi yang terpenting adalah apa yang dilakukan tokoh sehingga pembaca dapat mengambil esensi atau nilai-nilai yang terkandung

mengikuti setan yang menyebabkan terbukanya aurat orang tua manusia (Adam dan Hawa). QS. Al-A'raf [7]: 31 berisi perintah memkai pakaian indah setiap memasuki masjid (tempat ibadah). QS. Al-A'raf [7]: 35 membahas tentang kewajiban taat pada tuntunan Allah yang disampaikan para Rasul-Nya. 
di dalam kisah itu. Penulis juga berasumsi bahwa makna kisah bani Adam tersebut ditujukan untuk semua manusia, baik muslim maupun non muslim, tidak hanya mereka (orang-orang Yahudi) yang harus mengambil nilai-nilai dari kisah tersebut.

Kedua, dua bani Adam dalam kisah tersebut memiliki karakter yang berbeda, sebagaimana manusia pada umumnya. Qabil adalah representasi dari seseorang yang memiliki tipikal mudah menyakiti siapapun dengan dalih apapun. Sementara Habil adalah sebaliknya. Habil menandakan sosok yang memiliki kepasrahan total kepada Tuhan. Jadi, dua bani Adam dalam kisah tersebut menunjukkan karakter baik dan buruk manusia. Ketiga, penulis melihat QS. Al-Ma'idah [5]: 27-31 mengurai suatu konflik yang ditimbulkan oleh Qabil ketika persembahannya tidak diterima sedangkan yang diterima adalah persembahan Habil. Karena di antara manusia ada yang memiliki sifat baik dan buruk (tesa dan sintesa), maka kapanpun dan dimanapun pasti akan terjadi konflik.

Jika ditinjau dari teori horizon teks, maka pertama kali kita perlu menelaah aspek kebahasaan dari ayat di atas. Terkait aspek kebahasaan ini penulis merujuk pada Tafsir Al-Misbah. Kata utlu dalam QS. Al-Maidah [5]: 27, kata tersebut berasal dari kata talayatlü artinya mengikuti. Kata watlu dalam ayat itu oleh Quraish Shihab tidak diartikan "ceritakanlah" melainkan "bacakanlah". 52 Penggunaan kata talā dalam ayat ini berarti membaca untuk objek bacaan yang suci. Tidak seperti kata qirā'at yang bisa digunakan untuk objek bacaan secara umum. Jadi, kata talā mengisyaratkan bahwa yang dibacakan dan disampaikan itu bukanlah bersumber dari Nabi melainkan dari wahyu Allah ta'ala (yang jelas kebenaannya). ${ }^{53}$

Kemudian kata naba' berarti berita, dimaksudkan untuk berita yang penting atau bermanfaat (lihat QS: 6: 60). Sedangkan

52 Quraish Shihab mengartikan "bacakanlah" sebab, pembaca sebuah kisah adalah orang yang mengikutkan penyebutan satu berita dengan berita yang sesudahnya, satu huruf atau kata dengan huruf atau kata yang lain. Ini tidak seperti Al-Thabari ataupun Al-Qurthubi yang memberi arti 'ceritakanlah'. Lihat M. Quraish Shihab, Tafsir Al-Misbah: Pesan, Kesan, dan Keserasian AlQur'an, hlm. 91.

${ }^{53}$ M. Quraish Shihab, Tafsir Al-Misbah: Pesan, Kesan, dan Keserasian Al-Qur'an, hlm. 91. 
kata Adam adalah Nabi Adam. Jadi putera Adam dalam ayat di atas adalah putera kandungnya yang bernama Qabil dan Habil. ${ }^{54}$ Selanjutnya adalah kata qurbānan (kurban) berasal dari kata qaruba artinya dekat, yaitu sesuatu yang dipersembahkan kepada Tuhan, baik berupa barang yang disedekahkan atau dalam bentuk melakukan ibadah tertentu. Namun kata tersebut lebih banyak dipahami mempersembahkan sesuatu yang bersifat material (lihat QS:3:183). ${ }^{55}$ Terakhir, pernyataan innamā yataqabbalullāhu min al-Muttaqin (sesungguhnya Allah hanya menerima dari para muttaqin), ini dalam arti penerimaan ditujukan untuk orang-orang yang secara ikhlas mempersembahkan kurbannya serta beramal karena Allah. ${ }^{56}$

Setelah pada ayat sebelumnya Habil menasehati Qabil yang mengancam akan membunuhnya, nasihat itu dilanjutkan dengan ucapan yang menggambarkan kasih sayang kepada saudaranya tersebut serta rasa takutnya kepada Allah yang diredaksikan dalam ayat ke-28. Menurut Al-Qurthubi, ayat tersebut menunjukkan kepasrahan Habil. Pendapat lain mengatakan bahwa makna firman Allah tersebut adalah jika engkau menggerakkan tanganmu untuk menzhalimiku, maka aku tidak akan berbuat kezhaliman. Sebab, sesungguhnya aku takut kepada Allah Tuhan seru sekalian alam. ${ }^{57}$

Kemudian makna bi itsmi pada QS. Al-Ma'idah [5]: 29 adalah dosa yang dikhususkan kepadaku karena kesalahankesalahan yang aku perbuat. Maksudnya, dosa-dosaku akan diambil dan ditimpakan kepadamu karena kezhalimanmu

${ }^{54}$ Selain Tafsir Al-Thabari, Al-Qurthubi, Ibnu Katsir, dan Al-Misbah, pendapat ini juga dikemukakan oleh Shalah Al-Khalidy, Kisah-Kisah AlQur'an; Pelajaran dari Orang-Orang Terdahulu, hlm. 87.

55 Kata qurban pada zaman dahulu adalah seperti sedekah dan zakat pada zaman kita. hanya saja kurban mereka diyakini bisa diketahui mana yang diterima dan yang tidak, sebagaimana diceritakan bahwa yang diterima itu karena ada api yang memakannya. Sedangkan qurban zaman kita saat ini adalah amal shalih (perbuatan-perbuatan baik), dan tidak ada jalan untuk mengetahui secara langsung mana yang diterima mana yang tidak. Lihat Abu Ja'far Muhammad bin Jarir Ath-Thabari, Tafsir Ath-Thabari, hlm. 725.

${ }^{56}$ M. Quraish Shihab, Tafsir Al-Misbah: Pesan, Kesan, dan Keserasian Al-Qur'an, hlm. 93. hlm. 90 .

\footnotetext{
${ }^{57}$ Muhammad bin Ahmad al-Anshari al-Qurthubi, Tafsir al-Qurthubi,
} 
terhadapku, dan engkaupun akan kembali dengan membawa dosamu karena membunuhku. ${ }^{58}$ Sementara itu, kata wa-itsmika adalah dosanya selain membunuhnya yaitu bermaksiat kepada Allah ta'ala dalam perbuatan-perbuatan lain (selain membunuh).

Sedangkan kata fa thawwa'at dalam QS. Al-Ma'idah[5]: 30 berasal dari kata yang seakar dengan kata tha' at dalam arti tunduk dalam keadaan rela. Makna fa thawwa'at yaitu ketaatan dan kerelaan hati yang lahir dari upaya nafsu mempengaruhi dan meyakinkan seseorang. Meskipun ada pergolakan jiwa antara kebaikan (larangan membunuh) dan keburukan (dorongan nafsu membunuh), tetapi Qabil memilih condong taat pada dorongan nafsu membunuh. Maka fa ashbaha pada mulanya berarti memasuki waktu pagi (antonim amsā) tetapi diikuti oleh min alKhāsirīn maknanya menjadilah ia seorang di antara kelompok orang-orang yang merugi. ${ }^{59}$

Al-Qurthubi membahas ayat ini dalam tiga hal, pertama, makna fa thawwa'at lahu nafsuhu adalah yakni hawa nafsunya membujuknya, menganggap mudah, mendorongnya, dan membentuk pendapat bahwa membunuh saudaranya merupakan suatu perkara yang ringan bagi dirinya. Kedua, ayat ini berisi penjelasan tentang kondisi orang-orang yang mempunyai perasaan iri, sehingga keiriannya itu menggiringnya untuk membinasakan diri sendiri karena membunuh orang yang paling dekat dengannya. Ketiga, fa ashbaḥa min al-Khāsirīn yakni dia (Qabil) merupakan bagian dari orang-orang yang merugi kebaikannya. ${ }^{60}$

Pada QS. Al-Ma'idah [5]: 31, Quraish Shihab mendefinisikan saw'àt adalah bentuk jama' dari saw'ah yang pada mulanya berarti sesuatu yang buruk atau tidak menyenangkan. ${ }^{61}$ Terkait dengan ayat di atas, maka keburukan dari saw'àt ini adalah bau busuk dan kerusakan yang terjadi pada mayat saudara yang telah dibunuh Qabil. Kata yā waylatā terdiri dari kata yā hlm. 90 .

${ }^{58}$ Muhammad bin Ahmad al-Anshari al-Qurthubi, Tafsir al-Qurthubi,

${ }^{59}$ M. Quraish Shihab, Tafsir Al-Misbah: Pesan, Kesan, dan Keserasian Al-Qur'an, hlm. 96-97.

${ }^{60}$ Muhammad bin Ahmad al-Anshari al-Qurthubi, Tafsir al-Qurthubi, hlm. 91-92

61 M. Quraish Shihab, Jilbab, Pakaian Wanita Muslimah, cet. I, (Jakarta: Lentera Hati, 2004), hlm. 46. 
(digunakan untuk memanggil) dan wayl yang berarti kebinasaan, serta tà digunakan untuk menggambarkan kesempurnaan dan kebesaran sesuatu. Jadi, secara harfiah, yā waylatā berarti wahai kebinasaan yang besar, hadirlah. ${ }^{62}$

Kalimat itu menggambarkan bahwa penutur sedang berada di puncak kesulitan atau keresahan. Maka ketika melihat suatu keanehan yang mengisyaratkan petunjuk, ia mengumpat menyadari kebodohannya dengan kata yā waylatā (celaka aku, mati aku). Di akhir ayat, Qabil digolongkan sebagai di antara orang-orang yang menyesal. Penggolongan ini karena penyesalannya bertingkat (tidak hanya satu). Ia menyadari kebodohannya (menuruti hawa nafsunya untuk membunuh), dosanya (akibat membunuh saudaranya), dan ketidaktahuannya menyelesaikan masalah (mengubur jenazah saudaranya). ${ }^{63}$

Al-Qurthubi mengatakan bahwa Allah ta'ala mengutus burung gagak karena suatu hikmah yaitu agar putera Adam dapat melihat bagaimana cara menguburkan orang yang meninggal. Hal ini sesuai dengan QS. Abasa [80]: 21. Selanjutnya penguburan yang dilakukan burung gagak terhadap burung gagak lainnya menjadi sebuah syariat yang kekal bagi seluruh manusia. ${ }^{64}$

Selain aspek kebahasaan perlu kiranya melihat pada aspek intratekstualitas ayat. Intratekstualitas adalah hubungan antara satu surat dengan surat yang lain di dalam al-Qur'an (munasabah ayat). Terkait dengan pembahasan ayat di atas, penulis akan menyajikan beberapa ayat yang memiliki relasi dengan QS. AlMa'idah [5]: 27-31. Pertama, tentang persembahan kurban (QS. Al-Ma'idah [5]: 27). Sebagaimana disinggung di awal bahwa istilah qaruba lebih sering dipahami mempersembahkan sesuatu secara material. Isyarat diterimanya kurban dalam masyarakat dahulu (Yahudi, dll) adalah bahwa kurban tersebut dilahap api. alQur'an merespon hal ini dalam QS. Ali Imran [3]: 183. Kedua, mengenai ucapan Habil bahwa ia akan diam meskipun Qabil

${ }^{62}$ M. Quraish Shihab, Tafsir Al-Misbah: Pesan, Kesan, dan Keserasian Al-Qur'an, hlm. 98.

${ }^{63}$ M. Quraish Shihab, Tafsir Al-Misbah: Pesan, Kesan, dan Keserasian Al-Qur'an, hlm. 99.

${ }^{64}$ Muhammad bin Ahmad al-Anshari al-Qurthubi, Tafsir al-Qurthubi, hlm. 94. 
membunuhnya yang termaktub dalam QS. Al-Ma'idah [5]: 28. Dalam QS. Al-Nisa' [4]: 93, Allah ta'ala memberi peringat an bagi siapa saja yang membunuh orang mukmin akan mendapat balasan yang setimpal. Ketiga, berkenaan dengan pembunuh memikul dosa yang dibunuh (QS. Al-Ma'idah [5]: 29). Ayat ini erat kaitannya dengan QS. Al-Ankabut [29]: 13. ${ }^{65}$

Terkait dengan intertekstualitas QS. Al-Ma'idah [5]: 27-31, penulis akan menyuguhkan hadits-hadits terkait, riwayat tentang kisah putra Adam (Qabil dan Habil) dalam Qishshah al-Qur'an, dan kisah putra Adam (Kain dan Habel) dalam Bibel. Penyajian ketiga data tersebut berfungsi untuk melihat lebih detail kisah putra Adam dalam al-Qur'an. Menurut satu pendapat, QS. AlMa'idah [5]: 29 memiliki makna yang hampir sama dengan hadits berikut;

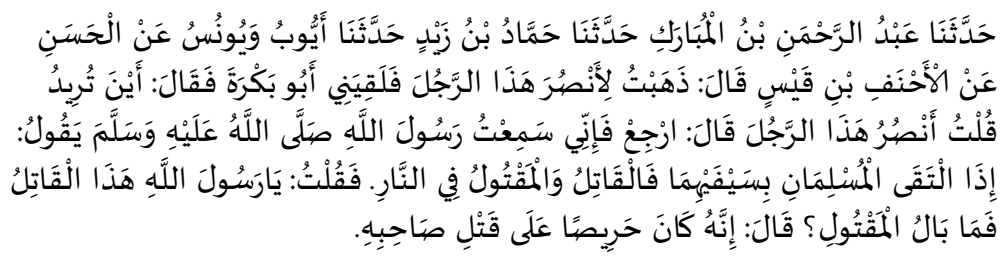

Artinya: "Apabila dua orang Muslim bertempur dengan pedangnya, maka orang yang membunuh dan dibunuh keduanya masuk neraka. Beliau ditanya, Ya Rasulullah, ini (sah bagi) pembunuh. Tapi bagaimana dengan yang dibunuh?. Beliau menjawab, "Sesungguhnya dia pun sangat ingin membunuh sahabatnya itu."66

Dalam sebuah riwayat yang bersumber dari Ibnu Katsir, dikatakan bahwa ketika itu Nabi Adam hendak menikahkan satu anak laki-laki dari satu kelahiran dengan anak perempuan dari kelahiran yang lain (sebab, Hawa selalu melahirkan bayi kembar laki-laki dan perempuan setiap kali persalinan). Jadi, Nabi Adam menjodoh-nikahkan putra-putrinya secara silang. Ketika itu, Qabil hendak dijodohkan dengan adik Habil yaitu Labuda. Sedangkan Habil dijodohkan dengan adik Qabil yang bernama Iqlima. Tetapi

${ }^{65}$ Agaknya dua ayat tersebut secara literal kontradiktif dengan QS. AnNajm [53]: 38. Tetapi, jika ditelisik lebih dalam ketiganya saling berhubungan dan menguatkan.

66 Imam Bukhari, Sahih Bukhari, no. 30, kitab al-Iman, dalam Maushu'ah hadits al-Syarif. 
Qabil menolak dan hanya mau menikah dengan Iqlima (adiknya sendiri yang lebih cantik). Maka, Nabi Adam memutuskan untuk menyuruh mereka mempersembahkan korban. Siapa yang diterima korbannya maka dialah yang berhak menikah dengan Iqlima. $^{67}$

Secara fisik, Qabil, meskipun sebagai saudara tertua, ia digambarkan memiliki badan yang lebih kecil dan lemah, namun tabiatnya kasar. Sedangkan Habil yang lebih muda, badannya besar dan kuat, tabiatnya sangat baik dan halus perasaannya. Maka, Nabi Adam membagi pekerjaan kepada kedua putranya itu sesuai dengan tabiatnya. Qabil diberi tugas bertani, mengolah tanah, mencangkul dan menebas hutan belukar. Sebab, tanah dan hutan belukar adalah benda mati yang tak membutuhkan perasaan halus dan cinta kasih secara langsung. Berbeda dengan Qabil, Habil yang berperangai baik dan halus budi diberi tugas untuk memelihara dan menggembala binatang ternak. Sebab, pekerjaan itu memang memerlukan kesabaran, ketelatenan, dan kehalusan rasa. $^{68}$

Maka, Qabil yang merupakan seorang petani, ia mempersembahkan hasil kebunnya (tetapi ia justru memberikan tanaman yang buruk ). Sementara itu, Habil sebagai penggembala (peternak), ia mempersembahkan seekor kambing yang paling bagus dan besar. Kemudian persembahan yang diterima adalah yang berasal dari Habil. Melihat hal itu, Qabil pun berkata, "Wahai Habil, aku akan membunuhmu." Lalu Habil menjawab,"Allah hanya menerima kurban dari orang-orang yang bertaqwa."69

Ada beragam cerita mengenai bagaimana Qabil melakukan pembunuhan terhadap adiknya. Dalam suatu riwayat, Qabil memukul kepala Habil dengan batu besar ketika Habil sedang tertidur. Tetapi ada juga yang mengatakan bahwa Qabil memukul adiknya dengan sebuah besi. Adapun tempatnya ada yang mengatakan di gunung Qasiun (utara Damaskus), ada pula yang

67 Dalam Tafsir Al-Qurthubi, nama saudara Qabil adalah Iqlimiya, sedangkan saudara Habil adalah Layudza. Lihat Muhammad bin Ahmad alAnshari al-Qurthubi, Tafsir al-Qurthubi, hlm. 88.

${ }^{68}$ Bey Arifin, Rangkaian Cerita dalam Al-Qur'an, hlm. 25-26.

${ }^{69}$ Lihat Ibnu Katsir, Qishshah al-Anbiya', hlm. 77. 
mengatakan di sebuah padang rumput, juga di hutan. Hemat penulis, beberapa riwayat itu bisa diterima dan tidak perlu dipertentangkan. Sebab, jika mau mencari kevalidan datanya, perlu melakukan jejak historis.

Kemudian ketika Habil telah terbunuh, dikisahkan bahwa Qabil merasa menyesal atas perbuatannya yang sangat kejam. Ia juga tidak tahu bagaimana menyikapi jenazah adiknya tersebut. Kemudian, ia kemana-mana memikul jenazah adiknya. Sampai suatu ketika ia melihat dua burung gagak berkelahi dan salah satunya mati. Selanjutnya, seekor gagak yang masih hidup itu menggali tanah dan menguburkan mayat gagak yang mati. Melihat hal itu, Qabil takjub sekaligus merasa sangat bodoh dibanding burung gagak yang bisa lebih dapat mengatasi persoalan mengubur jenazah dibanding dirinya. ${ }^{70}$

Kisah pembunuhan Qabil terhadap Habil ini juga terdapat di dalam Bibel. Dalam Kitab kejadian 4-16 menyatakan bahwa Adam dan Hawa memiliki dua putra: Qabil dan adiknya, Habil. Ketika menginjak usia dewasa, Qabil dan Habil mempersembahkan kurban kepada Allah. Tetapi, hanya persembahan Habil yang diterima-Nya. Ketika menyadari hal ini, Qabil sangat geram. Dalam keadaan marah serta frustasi yang meluap-luap, ia membunuh Habil. Allah mengutuk dan menghukum Qabil atas pembunuhan ini. Kisah tersebut nyaris identik dengan kisah yang dipaparkan Al-Qur'an, tetapi dengan beberapa rincian tambahan mengenai penolakan Habil untuk memerangi saudaranya, Qabil. ${ }^{71}$

Situasi ayat QS. Al-Ma'idah [5]: 27 pertama kali diturunkan adalah berkenaan dengan bani Nadhir. Orang-orang Yahudi dari Bani Nadhir merencanakan untuk membunuh Rasulullah. Ini terjadi pada saat beliau mendatangi mereka bersama beberapa orang sahabat, agar mereka mau membantu membayar tebusan bagi dua orang dari Bani Amir yang dibunuh Amr bin Umayyah adh-dhamry. "Kami akan membantumu wahai Abul Qasim. Sekarang duduklah disini, biar kami menyiapkan kebutuhanmu," kata orang-orang Yahudi Bani Nadhir. Beliau duduk di pinggir

${ }^{70}$ Bey Arifin, Rangkaian Cerita dalam Al-Qur'an, hlm. 36.

${ }^{71}$ Lihat Jerald F. Dricks, Salib di Bulan Sabit Dialog Antariman IslamKristen, terj. Ruslani, (Jakarta: Serambi Ilmu Semesta, 2006), hlm. 20. 
tembok salah satu dari rumah mereka, disamping beliau ada Abu Bakar, Umar, Ali dan beberapa shahabat yang lain. Ketika melihat Rasulullah telah duduk di tempat yang telah ditentukan, sebagian mereka justru memanfaatkan situasi, yaitu dengan diam-diam hendak membunuh Rasul. Merekapun berunding untuk menjatuhkan batu penggiling dari atas Rasulullah. Ketika orangorang Yahudi hendak merencanakan niat jahat mereka, Jibril turun kepada Rasulullah dan memberitahukan rencana orangorang Yahudi. ${ }^{72}$

Maka turunlah ayat tersebut sebagai perumpamaan pengkhianatan yang dilakukan orang-orang Yahudi Bani Nadhir dan pemenuhan janji yang dilakukan orang-orang mukmin. Keduanya direpresentasikan dalam kisah Qabil dan Habil saat mempersembahkan korban. Ayat ini membicarakan tentang tabiat manusia di dunia ini yaitu baik dan buruk. Sosok Qabil adalah simbol representasi orang berperangai buruk, sedangkan Habil adalah sebaliknya.

Dengan demikian, ayat ini turun sebagai respon terhadap tindakan pengkhianatan yang dilakukan orang-orang Yahudi Bani Nadhir kepada Rasulullah dan para sahabat. Allah memerintahkan Rasulullah untuk membacakan kisah tersebut untuk mengingatkan bahwa kejahatan sudah ada sejak dahulu yang direpresentasikan oleh Qabil yakni membunuh Habil (tanpa Habil menyakitinya). Menyerang orang yang diam, tidak bersalah itu tidak baik. Seperti yang dilakukan orang-orang Yahudi Bani Nadhir ini tidak baik.

Dengan teori horizontversmelcung-nya Gadamer, didapati bahwa QS. Al-Ma'idah [5]: 27-31 ini membicarakan tentang bagaimana mengatasi persoalan atau konflik. Konflik berarti pertentangan atau percekcokan. ${ }^{73}$ Konflik menjadi unsur terpenting dalam kehidupan manusia. ${ }^{74}$ Karena itulah manusia disebut sebagai makhluk konfliktis (homo conflictus) yaitu

72 Saidurrahman, "Kisah dan Pandangan Orang-orang Yahudi terhadap Islam”, dalam jurnal Theologia, vol. 25, no. 2, Juli-Desember 2014.

73 Lihat WJS. Poerwadarminta, Kamus Umum Bahasa Indonesia, (Jakarta: Balai Pustaka, 1976), hlm. 746.

${ }^{74}$ Konflik memiliki fungsi positif, menjadi dinamika sejarah manuisa, menjadi entitas hubungan sosial, dan sebagai bagian dari proses pemenuhan kebutuhan dasar manusia. lihat Novri Susan, Pengantar Sosiologi Konflik dan Isu-Isu Konflik Kontemporer, (Jakarta: Prenada Media Group, 2010), hlm. 7-8. 
makhluk yang selalu terlibat dalam perbedaan, pertentangan dan persaingan baik sukarela maupun terpaksa. Pertentangan tersebut dapat berupa ide maupun fisik. ${ }^{75}$ Tetapi, tidak semua konflik memberi efek negatif. Konflik bahkan menjadi mekanisme perubahan-perubahan sosial masyarakat. ${ }^{76}$

Setiap konflik pasti memiliki dinamika. Di antara dinamika konflik menurut Fisher adalah prakonflik, konfrontasi, krisis, akibat, dan pasca konflik. ${ }^{77}$ Jika konflik dalam kisah Qabil dan Habil didinamikakan, maka prakonfliknya adalah situasi yang membentuk konflik, yaitu tidak diterimanya persembahan kurban Qabil. Hal ini kemudian menimbulkan konfrontasi yaitu Qabil mengancam akan membunuh Habil, sedangkan Habil membalas menasehatinya dengan perkataan yang baik. Pada akhirnya terjadilah krisis (puncak konflik) yaitu pembunuhan terhadap Habil. Akibatnya, Habil terbunuh. Kemudian pada tahap pascakonflik, Qabil menyesal dan merugi.

Tetapi kisah Qabil dan Habil di atas tidak hanya membicarakan tentang konflik. Namun, kisah tersebut sekaligus mengandung pesan-pesan untuk menyelesaikan konflik yang ada, terutama konflik antar individu (interpersonal conflict). Secara keseluruhan, ada beberapa pesan solusi konflik yang terkandung di dalam QS. Al-Ma'idah [5]: 27-31. Pertama, manusia harus menghadapi konflik dengan kepala dingin, tidak mudah tersulut isu, panik, apalagi emosi. Ayat ke-27 mengisyaratkan bahwa setiap konflik perlu diklarifikasi terlebih dahulu. Hal ini ditunjukkan oleh sikap Habil ketika Qabil berkata, "Aku akan membunuhmu." Habil bersikap tenang dan menjawab, "Sesungguhnya Allah hanya menerima korban dari orang-orang yang bertaqwa." Jawaban Habil ini mengindikasikan bahwa dengan ketenangannya, ia memberi ruang berpikir (klarifikasi) pada pernyataan Qabil untuk menghindari kesalahpahaman. Ia

75 Konflik muncul dalam skala yang berbeda seperti konflik antar individu (interpersonal conflict), antar kelompok (intergroup conflict), antara kelompok dengan negara (vertical conflict), maupun antar negara (inter-state conflict).

76 Novri Susan, Pengantar Sosiologi Konflik dan Isu-Isu Konflik Kontemporer, hlm. 59.

77 Simon, Fisher, dkk, Manajemen Konflik ketrampilan dan Strategi untuk Bertindak (Jakarta: British Council, 2000), hlm. 102-103. 
juga menyampaikan gagasan tentang taqwa sebagai jalan mendekatkan diri kepada Allah. Jadi, sikap Habil ini juga mengarah pada isyarat bagaimana pihak-pihak yang berkonflik ini masing-masing dapat menemukan 'cahaya' kebenaran, agar konflik tidak semakin berkepanjangan.

Kedua, ketika seseorang terjebak dalam pusaran konflik, di mana upaya-upaya yang dipaparkan pada poin pertama di atas telah dilakukan namun belum berhasil keluar dari ketegangan, maka hendaknya bertawakkal pada Allah. Hal ini tidak hanya dapat menyelesaikan konflik tanpa berkonflik, menyelesaikan masalah tanpa masalah, melainkan juga dapat menciptakan kedamaian dan keharmonisan. Ketiga, tanpa membalas perlawanan sebagai upaya memutus siklus kekerasan. Artinya, kekerasan tidak dibalas dengan kekerasan. Itulah mengapa Habil tidak mau melawan Qabil. Tetapi ini bukan berarti bahwa Habil tidak berusaha melindungi diri. Manusia tidak mungkin bertahan hidup tanpa mampu melindungi diri. Habil melakukannya dengan kehalusan budi, yaitu menasehati Qabil agar menemukan jalan kebenaran. Ini sesuai dengan QS. Al-Ma'idah [5]: 28-29.

Keempat, sikap kesewenang-wenangan, membenarkan diri sendiri, tidak mau membuka hati dan pikiran akan menjerumuskan manusia dalam puncak konflik. Sikap inilah yang ditunjukkan Qabil dalam QS. Al-Ma'idah [5]: 30. Kelima, ketika konflik memuncak dan pecah, maka pada akhirnya mereka yang sewenang-wenang tersebut akan mengalami kerugian. Kenyataannya, terbunuhnya Habil bukanlah solusi bagi Qabil, justru dengan kejadian itu Qabil memperoleh persoalan baru dalam hidupnya. Jadi, pada QS. Al-Ma'idah [5]: 31 ini menekankan bahwa berpikir sebelum bertindak itu sangat penting. Untuk mengatasi konflik, manusia harus membuat jarak dengan konflik tersebut supaya dapat berpikir jernih.

Dengan demikian, hermeneutika filosofi Hans-Georg Gadamer membantu proses pemahaman terhadap ayat al-Qur'an secara objektif-komprehensif. Melalui teori horizontverschmelzung-nya, kisah Qabil dan Habil di dalam alQur'an dapat ditarik signifikansi maknanya yang tidak terbatas oleh ruang dan waktu. Ia tidak sekedar merefleksikan kejadian di masa lalu yang telah selesai, melainkan memiliki makna yang 
selalu kontemporer sepanjang masa, yaitu tentang konflik antar manusia dan solusinya. Dengan signifikansi makna yang universal tersebut sekaligus menjawab pertanyaan mengapa kisah ini ditampilkan oleh al-Qur'an.

\section{Kesimpulan}

Dengan teori horizontverschmelzung yang diramu HansGeorg Gadamer membuktikan bahwa hermeneutika dapat digunakan untuk mengungkap universalitas al-Qur'an. Teks kisah Qabil dan Habil yang merefleksikan pembunuhan di masa lalu, dengan analisis hermeneutika dapat dipetik pesan-pesan terdalamnya. Sehingga, teks tersebut menjadi risalah yang selalu baru dan objektif untuk masa kini dan mendatang. Ideal moral atau meaningfull sense dari ayat tersebut adalah bahwa setiap manusia pasti memiliki konflik. Untuk mengatasinya, pertama, ia harus berkepala dingin, tidak mudah tersulut isu, panik, emosi, dan konflik tersebut perlu diklarifikasi terlebih dahulu. Kedua, bertawakkal pada Allah. Ketiga, kekerasan tidak dibalas dengan kekerasan. Keempat, tidak sewenang-wenang atau menutup hati dan pikiran. Terakhir, berpikir jernih sebelum bertindak.

Dengan demikian, signifikansi makna kisah Qabil dan Habil di dalam al-Qur'an tidak terbatas oleh ruang dan waktu. Kendati ayat tersebut turun dengan alasan khusus, merespon sikap Bani Nadhir, namun pesannya sangat universal. Ia tidak sekedar merefleksikan kejadian pembunuhan di masa lalu yang telah selesai, melainkan memiliki makna yang selalu kontemporer sepanjang masa, yaitu tentang konflik antar manusia dan solusinya. Wa Allahu a'lam. 


\section{DAFTAR PUSTAKA}

Achmad. "Mutawalli al-Sya'rawi dan Metode Penafsirannya: Studi atas Surah Al-Ma'idah 27-34” dalam Jurnal Al-Daulah vol. 1 No 2, Juni 2013.

Al-Khalidy, Shalah. Kisah-Kisah Al-Qur'an; Pelajaran dari Orang-Orang Terdahulu, jilid III, cet.I, Jakarta: Gema Insani Press, 2000.

Al-Qurthubī, Muhammad bin Ahmad al-Anshārì. Tafsìr alQurthubỉ. Beirut: Dār al-Maktabah al-'Alamiyyah, 1971.

Arifin, Bey. Rangkaian Cerita dalam Al-Qur'an, cet.15. Bandung: Alma'arif, 1996.

Dricks, Jerald F. Salib di Bulan Sabit Dialog Antariman Islam-Kristen, terj. Ruslani, Jakarta: Serambi Ilmu Semesta, 2006.

Faiz, Fahruddin. Hermeneutika Al-Qur'an Tema-tema Kontroversial. Yogyakarta: Elsaq Press, 2005.

Fisher, Simon, dkk.Manajemen Konflik ketrampilan dan Strategi untuk Bertindak. Jakarta: British Council, 2000.

Gadamer, Hans-Georg. Truth dan Method, London: Continuum, 2004

Gusmao, Martinho G. da Silva. Hans-Georg Gadamer: Penggagas Filsafat Hermeneutik Modern yang Mengagungkan Tradisi. Yogyakarta: Kanisius, 2012.

K. Bertens, Filsafat Barat Abad XX Inggris-Jerman, Jakarta: Gramedia, 1983.

Katsir, Ibnu. Qishshah al-Anbiya', terj. Didi Rosyadi, cet.1. Jakarta: Al-Kautsar, 2011.

Palmer, Richard E. Hermeneutika Teori Baru Mengenai Interpretasi. Yogyakarta: Pustaka Pelajar, 2005.

Saidurrahman, "Kisah dan Pandangan Orang-orang Yahudi terhadap Islam", dalam jurnal Theologia, vol.25, no.2, JuliDesember 2014.

Shihab, M. Quraish. Jilbab, Pakaian Wanita Muslimah, cet. I. Jakarta: Lentera Hati, 2004. 
Shihab, M. Quraish. Tafsir Al-Misbah: Pesan, Kesan, dan Keserasian Al-Qur'an.Jakarta: Lentera Hati, 2002.

Susan, Novri. Pengantar Sosiologi Konflik dan Isu-Isu Konflik Kontemporer, Jakarta: Prenada Media Group, 2010.

Syamsuddin, Sahiron. "Hermeneutika Hans-Georg Gadamer dan Pengembangan Ulumul Qur'an dan Pembacaan AlQur'an pada Masa Kontemporer" dalam M. Nur Kholis Setiawan dkk, Upaya Integrasi Hermeneutika dalam Kajian Qur'an dan Hadis (Teori dan Aplikasi). Yogyakarta: Lembaga Penelitian UIN Sunan Kalijaga, 2011.

Syamsuddin, Sahiron. Hermeneutika dan Pengembangan Ulumul Qur'an. Yogyakarta: Pesantren Leidecker, Nawesea Press, 2009.

Syari'ati, Ali. On the Sociology of Islam, terj. Hamid Algar, Yogyakarta: Rausyanfikr, 2012.

Wahyudi, Yudian. Ushul Fiqh versus Hermeneutika, Membaca Islam dari Kanada. Yogyakarta: Nawesea Press, 2007.

Zuhdi, M. Nurdin. Pasaraya Tafsir Indonesia: Dari Kontestasi Metodologi hingga Kontekstualisasi. Yogyakarta: Kaukaba Dipantara, 2014. 